Published in final edited form as:

Am J Physiol Gastrointest Liver Physiol. 2006 September ; 291(3): G510-G517.

\title{
Role of mTOR signaling in intestinal cell migration
}

\author{
J. Marc Rhoads ${ }^{1}$, Xiaomei Niu ${ }^{1}$, Jack Odle ${ }^{2}$, and Lee M. Graves ${ }^{3}$ \\ 1Department of Pediatrics and Research Institute, Ochsner Clinic Foundation, New Orleans, \\ Louisiana \\ 2Department of Animal Sciences, North Carolina State University, Raleigh \\ 3Department of Pharmacology, School of Medicine, University of North Carolina, Chapel Hill, North \\ Carolina
}

\section{Abstract}

An early signaling event activated by amino acids and growth factors in many cell types is the phosphorylation of the mammalian target of rapamycin (mTOR; FRAP), which is functionally linked to ribosomal protein s6 kinase $\left(\mathrm{p} 70^{\mathrm{s} 6 \mathrm{k}}\right)$, a kinase that plays a critical regulatory role in the translation of mRNAs and protein synthesis. We previously showed that intestinal cell migration, the initial event in epithelial restitution, is enhanced by L-arginine (ARG). In this study, we used amino acids as prototypic activators of mTOR and ARG, IGF-1, or serum as recognized stimulators of intestinal cell migration. We found that 1 ) protein synthesis is required for intestinal cell migration, 2) mTOR/ p70 ${ }^{\mathrm{s} 6 \mathrm{k}}$ pathway inhibitors (rapamycin, wortmannin, and intracellular $\mathrm{Ca}^{2}+$ chelation) inhibit cell migration, 3) ARG activates migration and $\mathrm{mTOR} / \mathrm{p}^{2} 0^{\mathrm{s} 6 \mathrm{k}}$ (but not ERK-2) in migrating enterocytes, and 4) immunocytochemistry reveals abundant $\mathrm{p} 70^{\mathrm{s} 6 \mathrm{k}}$ staining in cytoplasm, whereas phosphop $70^{\mathrm{s} 6 \mathrm{k}}$ is virtually all intranuclear in resting cells but redistributes to the periphery on activation by ARG. We conclude that $\mathrm{mTOR} / \mathrm{p} 70^{\mathrm{s} 6 \mathrm{k}}$ signaling is essential to intestinal cell migration, is activated by ARG, involves both nuclear and cytoplasmic events, and may play a role in intestinal repair.

\section{Keywords}

insulin-like growth factor-1; arginine; p70 s6 kinase; extracellular signal-regulated kinase-2; rapamycin

\begin{abstract}
Acute regulation of protein synthesis in mammalian cells is achieved through changes in the rate of translation of mRNA via alterations in peptide chain initiation. A critical step in this process is binding of mRNA to the $43 \mathrm{~S}$ preinitiation complex. Two key translational regulators in mammalian cells are ribosomal protein s6 kinase $\left(\mathrm{p} 70^{\mathrm{s} 6 \mathrm{k}}\right)$ and 4E-BP1, both of which are upstream of preinitiation. Both $\mathrm{p} 70^{\mathrm{s} 6 \mathrm{k}}$ and 4E-BP1 are tightly regulated by the mammalian target of rapamycin (mTOR). mTOR has been called the "nutrient sensor" of cells, capable of integrating environmental factors with an organism's ability to survive $(8,20)$. Peterson et al. (25) reported that amino acids stimulate an inhibitory interaction between mTOR and protein phosphatase $2 \mathrm{~A}$, placing $\mathrm{p} 70^{\mathrm{s} 6 \mathrm{k}}$ in the activated state. Conversely, mTOR is inhibited by individual and global amino acid withdrawal. Rapamycin (at nanomolar concentrations) blocks $\mathrm{p} 70^{\mathrm{s} 6 \mathrm{k}}$ activation by amino acids (15) and other agonists.
\end{abstract}

\footnotetext{
Address for reprint requests and other correspondence: M. Rhoads, Div. of Gastroenterology, Dept. of Pediatrics, Univ. of Texas Medical School at Houston, 6431 Fannin St., MSB 7.137, Houston, TX 77030 (e-mail: J.Marc.Rhoads@uth.tmc.edu)..

The costs of publication of this article were defrayed in part by the payment of page charges. The article must therefore be hereby marked "advertisement" in accordance with 18 U.S.C. Section 1734 solely to indicate this fact.
} 
Recent reports have examined the signaling pathways regulating the activity of mTOR/ $\mathrm{p} 70^{\mathrm{s} 6 \mathrm{k}}$ in mammals. Studies performed in rats showed that deficiency of dietary essential amino acids inhibit global rates of liver protein synthesis via blocking p70 ${ }^{\mathrm{s} 6 \mathrm{k}}$ and 4E-BP1 activation $(2,3)$. In these studies, oral administration of amino acids stimulated liver protein synthesis via the same mechanism. Neonatal piglet muscle tissues also were sensitive to activation of mTOR/ $\mathrm{p} 70^{\mathrm{s} 6 \mathrm{k}}$ in response to feeding (9). Bacterial lipopolysaccharide profoundly inhibited mTOR phosphorylation and muscle protein synthesis (21).

Our studies addressed the possibility that amino acid excess and arginine (ARG) in particular could promote $\mathrm{mTOR} / \mathrm{p} 70^{\mathrm{s} 6 \mathrm{k}}$ activation and, in turn, control the rate of enterocyte migration. Previous work (29) in piglet and rat enterocytes showed that ARG and bovine serum concentrate were the best stimulators of cell migration. We also found in those studies that cycloheximide blocked this effect, implicating mRNA translation in this process (M. Rhoads and W. Chen, unpublished observations). ARG was of particular interest because of its potential role in treating infants with bowel disease. We and others $(5,31)$ have demonstrated severe ARG deficiency in premature infants who develop necrotizing enterocolitis. Even more important, Amin et al. (1) showed a prophylactic effect of oral and intravenous ARG against necrotizing enterocolitis in a cohort of premature infants.

\section{MATERIALS AND METHODS}

\section{Materials}

The S6 peptide was synthesized by Dr. D. Klapper (University of North Carolina, Chapel Hill, NC). Rabbit anti-p70s6 kinase antibody (A300-510) was purchased from Bethyl Laboratories (Montgomery, TX). Phospho-p70 S6 kinase (Thr421/Ser424) antibody (\#9204) was from Cell Signaling Technology (Beverly, MA). Goat anti-ERK2 rabbit polyclonal antibody (sc-154) and p-ERK mouse monoclonal antibody (sc-7383) were from Santa Cruz (La Jolla, CA). IGF-1 (I13769), anti-actin (A2066), L-arginine (A3784), wortmannin (W1628), rapamycin (R0395), and dimethyl sulphoxide (D2650) were purchased from Sigma (St. Louis, MO). MEM amino acids (\#0032) and MEM nonessential amino acids (\#03643) were from GIBCO (Carlsbad, CA). BAPTA-AM was obtained from Biomol (Plymouth Meeting, PA) and prepared in $\mathrm{Me}_{2} \mathrm{SO}_{4}$. Bovine serum concentrate was kindly provided by Proliant (Ames, IA). Alexa-Fluor donkey anti-rabbit IgG (\#A-21206), anti-goat IgG (\#A-11057), DAPI (D1360), and Prolong Gold Anti-fade Reagent (P36930) were all from Molecular Probes (Eugene, OR).

\section{Cells}

Cdx-2 cells, a transformed rat crypt IEC-6 cell line, was obtained from Dr. J.-Y. Wang (University of Maryland, Baltimore, MD). The cells were maintained in DMEM (Sigma D6046) supplemented with 5\% (vol/vol) FBS, 0.5\% ITS+1 liquid media supplement (Sigma I2521), $100 \mathrm{uU} / \mathrm{ml}$ penicillin, $100 \mu \mathrm{g} / \mathrm{ml}$ streptomycin (Sigma P4458), and $4 \mathrm{mM} \mathrm{IPTG} \mathrm{(Sigma}$ I6758), which served as an inducer, and were grown at $37^{\circ} \mathrm{C}$ in $5 \% \mathrm{CO}_{2}$. In some studies, cells were grown in a medium that contained concentrations of amino acids resembling those of serum, called Basal Medium (Eagle) with Earle's Salts (BME; Atlanta Biologicals, Norcross, GA). In other experiments, cells were treated with HBSS (Sigma H0887) containing (in g/l) $0.185 \mathrm{CaCl}_{2}, 0.097 \mathrm{MgSO}_{4}, 0.4 \mathrm{KCl}, 0.06 \mathrm{KH}_{2} \mathrm{PO}_{4}, 0.35 \mathrm{NaCl}, 0.048 \mathrm{Na}_{3} \mathrm{HPO}_{4}, 1$ glucose, and 0.011 phenol red.

\section{Migration assay}

We used intestinal monolayer wounding with a razor blade, as described by McCormack et al. (23) to determine whether amino acids stimulate intestinal cell migration, as previously described (29). Cdx2 cells were plated in six-well plates. After $80 \%$ confluence was reached, the cells were serum starved in BME overnight to achieve growth quiescence. The cells were 
pretreated with $50 \mathrm{nM}$ rapamycin and $500 \mathrm{nM}$ wortmannin for $30 \mathrm{~min}$. IGF-1 (10 ng/ml), 2x amino acids ( $2 \times \mathrm{AA})$, or $4 \mathrm{mM}$ arginine were added into the cells immediately, followed by scratching a $2 \times 0.5-\mathrm{cm}$ wound across the cell layer with a razor blade. Cells migrated for 16 or $24 \mathrm{~h}$ before being fixed with $2 \%$ formaldehyde. The cell migration was measured by using Scion image software to determine surface area in micrometer squared per micrometer of cut length.

\section{p70 S6K immunoblotting}

Cells were seeded in six-well plates. After $80 \%$ confluence was reached, cells were made

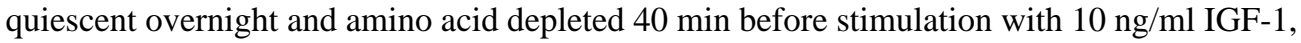
$4 \mathrm{mM}$ arginine, or $2 \times \mathrm{AA}$. Certain groups were pretreated for $30 \mathrm{~min}$ with $50 \mathrm{nM}$ rapamycin or $500 \mathrm{nM}$ wortmannin. At the end of the treatment, cells $\left(1 \times 10^{6}\right)$ were lysed with RIPA buffer containing protease inhibitor cocktail (Sigma p8340), incubated at $4^{\circ} \mathrm{C}$ for $15 \mathrm{~min}$ with gentle rocking. After sonication, the cell lysates were centrifuged at $16,000 \mathrm{~g}$ for $10 \mathrm{~min}$ at $4^{\circ} \mathrm{C}$.

Protein concentration of the cell lysates was determined by the Lowry method using the BioRad DC Protein assay kit (Bio-Rad, Hercules, CA). An equal volume of $2 \times$ Laemmli sample buffer was added, and the samples were boiled for $5 \mathrm{~min}$. Thirty micrograms of protein were separated on 7.5\% SDS-PAGE for $\mathrm{p} 70^{\mathrm{s} 6 \mathrm{k}}$ and were then electroblotted onto nitro-cellulose membranes (Bio-Rad). Membranes were blocked in blocking buffer [5\% nonfat dry milk in Tris-buffered saline, $\mathrm{pH} 7.6,0.05 \%$ (vol/vol) Tween-20 (TBST)] for $1 \mathrm{~h}$ at room temperature and incubated with the relevant antibodies in blocking buffer overnight at $4^{\circ} \mathrm{C}$. After being washed with TBST, blots were incubated with the appropriate peroxidase-conjugated secondary antibody for $1 \mathrm{~h}$ at room temperature. Bands were detected with an enhanced chemiluminescence detection kit (ECL Plus, Amersham Biosciences). The quantitative data were obtained using a computer densitometer (Quantity One, Bio-Rad).

\section{Immunoprecipitation Assay for p70s6k}

After wounding and treatments, $10^{7}$ cells were lysed by shaking in Tris/Triton lysis buffer (20 $\mathrm{mM}$ Tris, pH 7.5, $137 \mathrm{mM} \mathrm{NaCl}, 1 \%$ Triton X-100, 10\% glycerol, 2 mM EDTA, $0.5 \mathrm{mM}$ phenylmethylsulfonyl fluoride, $5 \mathrm{mg} / \mathrm{ml}$ leupeptin, $10 \mathrm{nM}$ calyculin A, and $148 \mu \mathrm{M} \mathrm{Na} 3 \mathrm{VO} 4$ ) at $4^{\circ} \mathrm{C}$ for $1 \mathrm{~h}$. Cell lysates were then spun for $10 \mathrm{~min}$ at $16 \mathrm{~g}$, supernatants were saved, and protein concentration was determined. The samples were immunoprecipitated using a rabbit polyclonal antibody to $\mathrm{p} 70^{\mathrm{s} 6 \mathrm{k}}$. The polyclonal antibody was bound to protein A-agarose beads $(20 \mu \mathrm{l})$, and p $70^{\mathrm{s} 6 \mathrm{k}}$ activity was assayed in $20 \mathrm{mM}$ HEPES, pH 7.3, $10 \mathrm{mM} \beta$-glycerophosphate, $1.5 \mathrm{mM}$ EGTA, $0.1 \mathrm{mM} \mathrm{Na}_{3} \mathrm{VO}_{4}, 1 \mathrm{mM}$ dithiothreitol, $10 \mathrm{mM} \mathrm{MgCl}_{2}$, and $50 \mathrm{mM}[\gamma-32 \mathrm{P}]$ ATP $(1,000 \mathrm{mCi} / \mathrm{mmol})$ plus $250 \mu \mathrm{M}$ of a $\mathrm{COOH}$-terminal peptide (QAFPMISKRPEHLRMNL) of the p70 ${ }^{\mathrm{s} 6 \mathrm{k}}$ (kindly provided by Dr. J. Weiel, Glaxo-Wellcome) in a final reaction volume of $60 \mu$. The assay was performed at $30^{\circ} \mathrm{C}$ for $20 \mathrm{~min}$ with constant shaking in an Eppendorf 5436 Thermomixer. The reaction was terminated by the addition of $20 \mu \mathrm{l}$ of $100 \mathrm{mM}$ EDTA (pH 7.0); the samples were centrifuged for $5 \mathrm{~min}$ at 13,000 $\mathrm{g}$, and the supernatant $(40 \mu \mathrm{l})$ was spotted on Whatman P-81 paper. The papers were washed in $10 \%$ phosphoric acid, and the radioactivity incorporated into the $\mathrm{p} 70^{\mathrm{S} 6 \mathrm{~K}}$ peptide was determined by liquid scintillation counting.

\section{Immunocytochemistry}

Cdx2-transformed IEC-6 cells were grown on glass coverslips in 24-well plates. Cells were serum-starved in BME for $24 \mathrm{~h}$ after reaching $80 \%$ confluence. The cells were then treated with $4 \mathrm{mM}$ ARG or $10 \% \mathrm{FBS}$ for 30 or $60 \mathrm{~min}$. Wounds were made by clearing the cells from one-half of the coverslip with a razor blade; and cells were allowed to migrate for $18 \mathrm{~h}$ after addition of $10 \%$ of FBS to the BME. Then, cells were fixed for 3 min in cold acetone. Nonspecific binding was blocked by incubating the coverslip with 5\% normal donkey serum 
in $1 \%$ BSA in PBS for $15 \mathrm{~min}$ at room temperature followed by incubation for 90 min with $1 \%$ BSA in PBS containing primary antibodies: goat anti-p70 $0^{\mathrm{s} 6 \mathrm{k}}$ (1:200 dilution), rabbit antiphospho-p70 $0^{\mathrm{s} 6 \mathrm{k}}$ antibody (1:200 dilution) and rabbit anti-FAK (1:100 dilution). Coverslips were washed three times, 5 min each with PBS, and then labeled with a 1:500 dilution of combined donkey Alexa-Fluor 488 anti-rabbit IgG and Alexa-Fluor 568 anti-goat IgG for 30 $\mathrm{min}$ at room temperature with light shielding. For visualization of nuclei, coverslips were stained with DAPI at 1:5,000 dilution in PBS for $2 \mathrm{~min}$. Subsequently, coverslips were mounted with Prolong Gold Antifade Reagent, and fluorescent images were captured using a Zeiss deconvolution microscope equipped with Slidebook (Intelligent Imaging Innovations, Denver, $\mathrm{CO})$ software under a $\times 60$ oil-immersion objective and $\times 10$ objective. The images were prepared and labeled using Adobe Photoshop 7.0 software.

\section{Statistical analysis}

Experiments were performed in triplicate. Results are reported as means \pm SE. Statistical comparisons were made by using one-way ANOVA (Statview4, Abacus concepts, Berkeley, CA). Statistical significance of difference between mean values was assessed with ANOVA $t$-tests. A $P$ value of $\leq 0.05$ was considered significant.

\section{RESULTS}

\section{Inhibitors of mTOR signaling inhibit cell migration}

We previously showed that ERK activation is essential to intestinal cell proliferation, a component of intestinal repair that takes place after restitution (28). To determine whether ARG or serum-stimulated cell migration is dependent on mTOR or MAP kinase signaling, we determined whether inhibitors of these pathways inhibited IEC cell migration rate response to ARG or bovine serum concentrate (BSC; Fig. 1A). In this and subsequent experiments, ARG was added at $4 \mathrm{mM}$, which was previously found to be the optimal concentration to stimulate migration (29). Rapidly migrating ARG- or BSC-treated cells were pretreated for $30 \mathrm{~min}$ with inhibitors. We studied the effects of rapamycin (a macrolide that forms a complex with the immunophilin FKBP12, which binds specifically to mTOR and inhibits its ability to phosphorylate substrates); the intra-cellular $\mathrm{Ca}^{2+}$ chelator BAPTA (which inhibits mTOR/ p70 $\left.{ }^{\mathrm{s} 6 \mathrm{k}}\right)$; and the ERK inhibitor PD98059 $(50 \mu \mathrm{M})$. Results showed that the migration rate of ARG- or BSC-stimulated cells was significantly reduced (by 30-50\%) when either rapamycin or BAPTA was present. The ERK inhibitor PD98059 had no statistically significant effect on ARG-stimulated migration or on BSC-stimulated migration. The findings were consistent with a role for $\mathrm{mTOR} / \mathrm{p} 70^{\mathrm{s} 6 \mathrm{k}}$ signaling but not MAPK signaling in the cell migration response to ARG.

\section{Protein synthesis is required for intestinal cell migration}

We next determined whether increasing the concentration of a mixture of essential and nonessential amino acids mimics ARG-stimulated migration. We have found that protein synthetic rate in intact intestinal tissues is dependent on the level of ambient amino acids (B. Corl, J. Odle, and M. Rhoads, unpublished observations). Cdx2-tranformed intestinal epithelial cell migration rates were measured in different media containing defined concentrations of amino acids. As shown in Fig. 1B, migration of cells incubated in an amino acid-free buffer (HBSS) was negligible. After $12 \mathrm{~h}$, the cells began to float off of the culture dish. However, cell migration rate was equivalent regardless of whether cells were incubated in BME $(0.5 \mathrm{~g} /$ 1 amino acids, mimicking human serum); in DMEM ( $1.7 \mathrm{~g} / \mathrm{l}$ amino acids); or in BME $+2 \times \mathrm{AA}$ $(1.8 \mathrm{~g} / \mathrm{l}$ amino acids). There was no stimulation by $2 \times \mathrm{AA}$ of migration, as was seen with ARG. We also determined whether $\mathrm{mTOR} / \mathrm{p} 70^{\mathrm{s} 6 \mathrm{k}}$ pathway inhibitors reduce basal cell migration. Figure 1B shows that the mTOR inhibitor rapamycin and the phospatidylinositol (PI) 3-kinase inhibitor wortmannin reduced basal migration by $>50 \%(\mathrm{P} \leq 0.05)$. Collectively, the above 
results suggest that protein synthesis and the mTOR signaling pathway are essential for optimal cell migration.

Although the 2xAA mixture given individually was necessary but not sufficient to stimulate migration, we hypothesized that growth factor-stimulated migration might be enhanced by supraphysiological levels of amino acids. Therefore, we compared migration response to IGF-1 in the low-amino acid medium $(0.5 \mathrm{~g} / \mathrm{l})$ with that in the presence of IGF-1 plus $2 \times A A(1.8 \mathrm{~g} /$ 1). Cell migration did not increase after IGF-1 was added to the low-amino acid medium, but cell migration increased by $64 \%$ in the presence of both IGF-1 and $2 \times \mathrm{AA}(P \leq 0.01$; data not shown). This observation indicates that amino acid levels and mTOR signaling, which have been shown to affect the rate of $5^{\prime}$-TOP mRNA (mRNAs with a 5' oligopyrimidine tract) translation, play an essential role in intestinal cell migration.

\section{Cellular $p 70^{\text {s6k }}$ but not ERK-2 activation is stimulated by wounding and ARG}

Given that cell migration was inhibited by mTOR pathway blockers, we needed to confirm that the same concentration of these inhibitors reduced $\mathrm{p} 70^{\mathrm{s} 6 \mathrm{k}}$ phosphorylation and activity. We also determined whether IGF-1 stimulated mTOR activity. Figure 2A shows one of three representative Western blots demonstrating that, in unwounded cells, the phosphorylation of $\mathrm{p} 70^{\mathrm{s} 6 \mathrm{k}}$ was enhanced by ARG and IGF-1. Additionally, cells in amino acid medium (BME) had a higher basal phosphorylation level than those in the balanced salt solution HBSS. The $\mathrm{p} 70^{\mathrm{s} 6 \mathrm{k}}$ phosphorylation level with ARG or IGF-1 was twofold higher in BME than in HBSS. The greater level of activation was evidenced not only by higher density on the phospho$\mathrm{p} 70^{\mathrm{s} 6 \mathrm{k}}\left(\mathrm{pp} 70^{\mathrm{s} 6 \mathrm{k}}\right)$ blot, but also by a mobility shift toward a higher molecular weight of the $\mathrm{p} 70^{\mathrm{s} 6 \mathrm{k}}$. Phosphorylation of $\mathrm{p} 70^{\mathrm{s} 6 \mathrm{k}}$ stimulated by ARG, amino acids, or IGF-1 was blocked by rapamycin (Fig. 2A) or wortmannin (Fig. 2B). However, ERK-2 phosphorylation was equivalent in cells bathed with no amino acids (HBSS) and in BME (with $0.5 \mathrm{~g} / 1$ amino acids). At 10 min after treatment, neither ARG nor IGF-1 activated ERK-2 (data not shown).

We determined whether ARG or IGF-1 activated ERK-2 at 30 min postwounding, at which time ERK-2 was expected to be activated. Figure 2C shows that wounding activated ERK-2 by twofold, but there was no further increase in ERK-2 phosphorylation after treatment with ARG or IGF-1. Also, there was no inhibition of ERK-2 by rapamycin. We concluded that, in wounded intestinal cells, the ERK and mTOR pathways appear to be regulated independently.

\section{ARG hyperstimulates $\mathrm{p} 70^{\mathrm{s} 6 \mathrm{k}}$ phosphorylation after mono-layer wounding}

We subsequently measured the kinetics of ARG activation of $\mathrm{p} 70^{\mathrm{s} 6 \mathrm{k}}$ in the enterocyte cell line using an in vitro kinase assay, which determines the phosphorylation activity toward a peptide component of ribosomal protein S6 (14) (Fig. 3A). In these studies, $4 \mathrm{mM} \mathrm{ARG}$ was added to DMEM, which contains only $0.4 \mathrm{mM}$ ARG. Over the 30-min study interval, ARG was found to stimulate p $70^{\mathrm{s} 6 \mathrm{k}}$ activity $2.0 \pm 0.4$-fold, an effect that peaked at $30 \mathrm{~min}$ and subsequently declined to baseline $(P \leq 0.01$ at $15 \mathrm{~min}$ and $P \leq 0.05$ at $30 \mathrm{~min}$ after ARG). Rapamycin reduced kinase activity to $50 \%$ of basal levels despite the presence of ARG $(P \leq 0.01$ compared with control cells).

These observations showed that amino acids stimulate $\mathrm{p} 70^{\mathrm{s} 6 \mathrm{k}}$ in intestinal epithelial cells. To determine whether wounding the cells stimulates $\mathrm{p} 70^{\mathrm{s} 6 \mathrm{k}}$ activity, Cdx2-tranformed IEC-6 cells were multiply wounded and harvested at different time intervals in DMEM with or without extra ARG, and activity of $\mathrm{p} 70^{\mathrm{s} 6 \mathrm{k}}$ was determined. Gradually, the $\mathrm{p} 70^{\mathrm{s} 6 \mathrm{k}}$ activity increased after wounding, reaching a peak of $1.9 \pm 0.04$-fold control levels at $1 \mathrm{~h}$ (in vitro kinase data, not shown). Thus both ARG and wounding the monolayer activate $\mathrm{p} 70^{\mathrm{s} 6 \mathrm{k}}$. The additive effects of ARG and wounding in IEC-6 cells are further demonstrated in Fig. 3B. Monolayers were multiply wounded in the presence of low ARG (BME that contains $0.12 \mathrm{mM} \mathrm{ARG)} \mathrm{or} \mathrm{high}$ 
ARG (4 mM that was added to BME). We found that at $30 \mathrm{~min}, 1 \mathrm{~h}$, and $8 \mathrm{~h}$ after wounding, ARG-supplemented cells had a higher phosphorylation level of $\mathrm{p} 70^{\mathrm{s} 6 \mathrm{k}}$ than unsupplemented cells. With the use of 1.0 (densitometry units) to normalize $\mathrm{p} 70^{\mathrm{s} 6 \mathrm{k}}$ phosphorylation of unwounded cells, at $30 \mathrm{~min}$, the phosphorylation was 2.3-fold with ARG versus 1.7-fold with BME; at 60 min, phosphorylation was 2.2-fold with ARG versus 1.6-fold with BME; and at $8 \mathrm{~h}$, phosphorylation was 1.2-fold versus 1.0-fold with BME. Microscopic observation showed that wound closure was almost complete at $8-10 \mathrm{~h}$. These findings indicated that ARG stimulates $\mathrm{mTOR} / \mathrm{p} 70^{\mathrm{s} 6 \mathrm{k}}$ activation in wounded intestinal cells just as it does in unwounded cells.

\section{ARG stimulates and rapamycin abolishes cytosolic localization of phospho-p $70^{s 6 \mathrm{k}}$ in intestinal cell migration}

Our studies determined intracellular localization of $\mathrm{p} 70^{\mathrm{s} 6 \mathrm{k}}$ and phospho-p $70^{\mathrm{s} 6 \mathrm{k}}$ to better understand the role of mTOR in intestinal cell response to ARG. Although p $70^{\mathrm{s} 6 \mathrm{k}}$ was abundant in the cytoplasm, mostly in the perinuclear region, it was also abundant at cell-cell contact sites at the periphery (Fig. 4). Mitotic figures exhibited extremely high immunoreactivity to $\mathrm{p} 70^{\mathrm{s} 6 \mathrm{k}}$ and $\mathrm{pp} 70^{\mathrm{s} 6 \mathrm{k}}$ (top left). Phosphorylated $\mathrm{p} 70^{\mathrm{s} 6 \mathrm{k}}$ (Fig. 4, panels on right) was particularly abundant in the nucleus and was more abundant in cells exposed to amino acids (BME) than in those bathed in a balanced salt solution (HBSS). We were consistently able to identify phosphorylated $\mathrm{p} 70^{\mathrm{s} 6 \mathrm{k}}$ in the nucleus using both anti-phospho-Thr421/Ser424 and anti-Thr389 (data not shown) antibodies. ARG treatment for $30 \mathrm{~min}$ had two measurable effects: an increase in total $\mathrm{p} 70^{\mathrm{s} 6 \mathrm{k}}$ immunostaining in the perinuclear region and an increase in cytosolic appearance of the phosphorylated form. This latter effect was also seen with fetal bovine serum treatment. Rapamycin administration, conversely, lowered the intensity of the immunoreactivity in the perinuclear region to that comparable with cells in BME, while preserving immunoreactivity at cell-cell contact sites. Additionally, rapamycin greatly reduced phosphorylated $\mathrm{p} 70^{\mathrm{s} 6 \mathrm{k}}$ staining in the cytoplasm and reduced nuclear levels close to those of cells in Hank's balanced salts solution (HBSS).

\section{DISCUSSION}

This study makes three main contributions toward understanding the physiology of intestinal cell migration and epithelial restitution. First, it demonstrates that amino acid sufficiency and protein synthesis are necessary for stimulation of intestinal cell migration. Second, we showed that the $\mathrm{mTOR} / \mathrm{p} 70^{\mathrm{s} 6 \mathrm{k}}$ pathway, most likely downstream of PI3-kinase, plays an obligatory role in this stimulation by ARG and growth factors. Third, although $\mathrm{p} 70^{\mathrm{s} 6 \mathrm{k}}$ is traditionally viewed as a cytoplasmic effector of translation, we identified an important nuclear localization of phosphorylated $\mathrm{p} 70^{\mathrm{s} 6 \mathrm{k}}$, some of which translocated to the cytosol after cellular activation by ARG.

\section{Role of amino acid signaling in intestinal restitution in vivo}

It has become dogma that host nutritional state has a major impact on intestinal recovery from infectious diarrhea and other intestinal disorders. For example, clinical studies in humans and pigs have shown that bowel repair is delayed in hosts with protein-calorie malnutrition (26, 33). Additionally, malnutrition, characterized by low circulating levels of total and specific amino acids, is associated with an increased risk of babies developing neonatal necrotizing enterocolitis $(5,31)$. The old theme of "resting the bowel" during intestinal disease has been replaced by abundant literature indicating that bowel rest may prolong villus atrophy. One candidate mediator by which enteral nutrients exert a trophic effect is glucagon-like peptide 2 , which is released by the ileum in response to enteral nutrition (7). 


\section{Role of $\mathrm{mTOR} / \mathrm{p} 70^{\mathrm{s} 6 \mathrm{k}}$ in cell physiology}

Previous research has identified a "nutrient sensor" function for $\mathrm{mTOR} / \mathrm{p} 70^{\mathrm{s} 6 \mathrm{k}}$, which may mediate a component of the starvation-refeeding response in the intestine. In muscle and liver cells, serum amino acid levels and, presumably, portal vein levels regulate mRNA translation and protein synthesis via mTOR and its effectors $\mathrm{p} 70^{\mathrm{s} 6 \mathrm{k}}$ and 4E-BP1. The latter control translation of 5'-TOP mRNA (mRNAs with a oligopyrimidine tract) and global mRNA translation, respectively (20). Additionally, mTOR activation is essential to cell proliferation, regulating the entry into the G1 phase of the cell cycle (30). In fibroblast migration, recent investigations by Berven et al. (6) showed that a number of mTOR pathway kinases interacts with the actin cytoskeleton in advancing lamellipodia. These kinases include mTOR, Akt, PI3kinase, protein kinase $\mathrm{B}$, and $\mathrm{p} 70^{\mathrm{s} 6 \mathrm{k}}$. Evidence for participation of $\mathrm{mTOR} / \mathrm{p} 70^{\mathrm{s} 6 \mathrm{k}}$ signaling in intestinal restitution during disease is supported by our recent studies showing increased levels of immunoreactive $\mathrm{p} 70^{\mathrm{s} 6 \mathrm{k}}$ localized to the tip of rotavirus-injured villi in the piglet jejunum (M. Rhoads and J. Odle, unpublished data).

We have presented evidence that amino acids may exert their beneficial effects on intestinal repair through activation of $\mathrm{mTOR} / \mathrm{p} 70^{\mathrm{s} 6 \mathrm{k}}$. Previously, investigators showed that $2 \times \mathrm{AA}$ greatly enhanced $\mathrm{p} 70^{\mathrm{s} 6 \mathrm{k}}$ in Chinese hamster ovary cells. When individual amino acids were removed, the two most important in preserving normal p70 ${ }^{\mathrm{s} 6 \mathrm{k}}$ activity were LEU and ARG (15). During the preparation of this manuscript, Ban et al. (4) showed that ARG and LEU were the best amino acids at stimulating pp $70^{\mathrm{s} 6 \mathrm{k}}$ in stationary IEC-6 cells.

Activation of $\mathrm{p} 70^{\mathrm{s} 6 \mathrm{k}}$ is accomplished through the phosphorylation of multiple SER/THR residues. One pathway involves PI3-kinase, which is inhibited by wortmannin and which phosphorylates PDK1 which, in turn, phosphorylates THR 229 on the p $70^{\mathrm{s} 6 \mathrm{k}}$ molecule, whereas mTOR (either directly or indirectly) phosphorylates other sites, for example, THR 389 in the catalytic domain of $\mathrm{p} 70^{\mathrm{s} 6 \mathrm{k}}(10)$. Thus our studies suggest that the enhancement of $\mathrm{p} 70^{\mathrm{s} 6 \mathrm{k}}$ by amino acids involves activation upstream of mTOR, because $\mathrm{p} 70^{\mathrm{s} 6 \mathrm{k}}$ phosphorylation was markedly reduced by the PI3-kinase inhibitor wortmannin.

Other investigators have clearly shown that the MAPKs, ERK-1 and -2, are activated during intestinal cell migration (12). However, Polk and Tong previously showed that ERK inhibition with PD98059 did not inhibit directed enterocyte migration (27). They did find that nonspecific tyrosine kinase and phospholipase $\mathrm{C}$ inhibitors inhibited migration. We confirm in the present studies that the MAPK inhibitor PD90859 did not inhibit ARG-stimulated migration. Collectively, these findings therefore suggest that the PI3-kinase/ mTOR/p70 ${ }^{\mathrm{s} 6 \mathrm{k}}$ pathway but not MAPK signaling is essential to ARG or serum-stimulated migration.

We have demonstrated in these studies that maximal intestinal cell migration requires growth factors or a supraphysiological dose of amino acid (higher than those in normal human serum, modeled by the medium BME). Cells in a balanced salt solution were incapable of migration. Previous studies have identified specific amino acids as essential activators of cell growth in the intestine. For example, mitogenesis in response to epidermal growth factor (EGF) or IGF-1 requires glutamine supplementation $(28,32)$. Another study (24) showed that prolonged exposure of intestinal cells to EGF produced a $70 \%$ increase in the maximal velocity of cellular amino acid uptake system L, indicating a cooperative relationship between growth factor and amino acid. Therefore, amino acids may be essential components of the repair process.

What is unknown is the exact mechanism and the molecular sensor of cellular amino acid levels. Very recent studies have implicated the tuberous sclerosis complex (TSC) proteins TSC 1 and TSC2 (which form a heterodimer TSC1/2) as the most likely cellular amino acid sensor. TSC1/2 and Rheb (Ras homolog enriched in brain) antagonize the mTOR signaling 
pathway via stimulation of GTP hydrolysis of Rheb (22). Amino acids have been shown to inhibit the TSC1/2 complex, allowing mTOR/p70 ${ }^{\mathrm{s} 6 \mathrm{k}}$ signaling.

An additional mechanism by which amino acids activate $\mathrm{mTOR} / \mathrm{p} 70^{\mathrm{s} 6 \mathrm{k}}$ was identified by Iiboshi et al. (16). They demonstrated that tRNA charging by amino acids (but not amino acid alcohols) activated Akt and $\mathrm{p} 70^{\mathrm{s} 6 \mathrm{k}}$. Because ARG provides additional stimulation even in the face of cellular amino acid sufficiency, we propose that tRNA charging may not be the primary mechanism of action of ARG.

\section{Subcellular localization of intestinal cell $p 70^{s 6 k}$}

We hypothesized that ARG treatment would increase the phosphorylation of $\mathrm{p} 70^{\mathrm{s} 6 \mathrm{k}}$ in the cytoplasm and that most $\mathrm{p} 70^{\mathrm{s} 6 \mathrm{k}}$ would reside in this location. Instead, we found that whereas most $\mathrm{p} 70^{\mathrm{s} 6 \mathrm{k}}$ was in the cytosol, activated (phosphorylated) $\mathrm{p} 70^{\mathrm{s} 6 \mathrm{k}}$ was nuclear. Only a small amount of nuclear phospho-p $70^{\mathrm{s} 6 \mathrm{k}}$ was seen in quiescent cells, but the addition of ARG brought about a major change, with the appearance of much of the $\mathrm{pp} 70^{\mathrm{s} 6 \mathrm{k}}$ in the cytosol. Rapamycin blocked this change. We do not believe that the nuclear isoform activated by ARG is either p $85 \mathrm{~S} 6 \mathrm{~K}$ or $\mathrm{p} 70^{\mathrm{s} 6 \mathrm{~K} 2}$, even though both are believed to reside in the nucleus. This is because our immunoblots did not show a prominent band at molecular mass 85 (Fig. 2, for example), even though the majority of pp $70^{\mathrm{s} 6 \mathrm{k}}$ was in the nucleus. Furthermore, the antibody from Cell Signaling that we used to identify pp70 $70^{\mathrm{s} 6 \mathrm{k}}$ was very unlikely to react with $\mathrm{S} 6 \mathrm{~K} 2$, because the latter is missing a THR 421 phosphorylation site and is affinity purified with phosphorylated peptide. Also, an antibody to S6K2 did not show nuclear reactivity in Cdx2-tranformed IEC-6 cells (X. Niu and M. Rhoads, unpublished observations).

Although the primary role of $\mathrm{p} 70^{\mathrm{s} 6 \mathrm{k}}$ is to regulate $5^{\prime}$-TOP mRNA translation in the cytosol, several previous studies have identified nuclear localization of $\mathrm{p} 70^{\mathrm{s} 6 \mathrm{k}}$ and mTOR. Edelmann et al. (11) showed that both $\mathrm{p} 70^{\mathrm{s} 6 \mathrm{k}}$ and a nuclear isoform became concentrated in localized spots in the nucleus at certain stages in the cell cycle. Kim and Khan (18) found that treatment with insulin or serum stimulated the activity of $\mathrm{p} 70^{\mathrm{s} 6 \mathrm{k}}$ both in the cytoplasm and nucleus. Stimulation with a tumor-promoting phorbol ester increased nuclear $\mathrm{p} 70^{\mathrm{s} 6 \mathrm{k}}$ while decreasing cytoplasmic $\mathrm{p} 70^{\mathrm{s} 6 \mathrm{k}}$. Kim and Chen (17) found that mTOR mutants with a nuclear localization signal boosted 5'-TOP-related translation, whereas a strong nuclear export signal led to a decrease in translation. The investigators suggested that nuclear shuttling of mTOR is required for the regulation of rapamycin-sensitive translation initiation. Berven et al. (6) showed that EGF stimulation of cells led to a redistribution of mTOR from the nucleus to the actin arc at the cell periphery, supporting this concept of nuclear-cytoplasmic shuttling.

Because our cells were more motile after ARG and serum, concomitant with a translocation of a significant portion of phosphorylated $\mathrm{p} 70^{\mathrm{s} 6 \mathrm{k}}$ to the cytosol, we suggest that $\mathrm{p} 70^{\mathrm{s} 6 \mathrm{k}}$ may be activated in the nucleus, streaming out to the cell periphery and subsequently undergoing dephosphorylation in the cytoplasm, perhaps after mRNA translation has occurred. Such movement would be analogous to movement to the actin arc of mTOR, Akt1, PDK1, and PI3kinase in Swiss 3 T3 fibroblasts treated with EGF (6). Further work will be required to prove this hypothesis.

\section{Potential clinical role of ARG in intestinal restitution}

Gookin et al. (13) recently showed that intestinal barrier recovery from an in vitro denuding injury was facilitated by ARG and serum. These studies and our current report underscore the potential usefulness of ARG in treating intestinal diseases. In fact, the growth of neonatal piglets is limited by ARG concentration in the formula (19). ARG is FDA approved as a dietary supplement and should be further investigated for infants and children with bowel disease. 


\section{ACKNOWLEDGMENTS}

We appreciate the technical expertise of Dr. Qiang Fu.

\section{REFERENCES}

1. Amin HJ, Zamora SA, McMillan DD, Fick GH, Butzner JD, Parsons HG, Scott RB. Arginine supplementation prevents necrotizing enterocolitis in the premature infant. J Pediatr 2002;140:425431. [PubMed: 12006956]

2. Anthony TG, Anthony JC, Yoshizawa F, Kimball SR, Jefferson LS. Oral administration of leucine stimulates ribosomal protein mRNA translation but not global rates of protein synthesis in the liver of rats. J Nutr 2001;131:1171-1176. [PubMed: 11285321]

3. Anthony TG, Reiter AK, Anthony JC, Kimball SR, Jefferson LS. Deficiency of dietary EAA preferentially inhibits mRNA translation of ribosomal proteins in liver of meal-fed rats. Am J Physiol Endocrinol Metab 2001;281:E430-E439. [PubMed: 11500297]

4. Ban H, Shigemitsu K, Yamatsuji T, Haisa M, Nakajo T, Takaoka M, Nobuhisa T, Gunduz M, Tanaka $\mathrm{N}$, Naomoto Y. Arginine and leucine regulate p70 S6 kinase and 4E-BP1 in intestinal epithelial cells. Int J Mol Med 2004;13:537-543. [PubMed: 15010853]

5. Becker RM, Wu G, Galanko JA, Chen W, Maynor AR, Bose CL, Rhoads JM. Reduced serum amino acid concentrations in infants with necrotizing enterocolitis. J Pediatr 2000;137:785-793. [PubMed: 11113834]

6. Berven LA, Willard FS, Crouch MF. Role of the p70 s6k pathway in regulating the actin cytoskeleton and cell migration. Exp Cell Res 2004;296:183-195. [PubMed: 15149849]

7. Burrin D, Guan X, Stoll B, Petersen YM, Sangild PT. Glucagon-like peptide 2: a key link between nutrition and intestinal adaptation in neonates? J Nutr 2003;133:3712-3716. [PubMed: 14608101]

8. Christie GR, Hajduch E, Hundal HS, Proud CG, Taylor PM. Intracellular sensing of amino acids in Xenopus laevis oocytes stimulates p70 S6 kinase in a target of rapamycin-dependent manner. J Biol Chem 2002;277:9952-9957. [PubMed: 11788584]

9. Davis TA, Nguyen HV, Suryawan A, Bush JA, Jefferson LS, Kimball SR. Developmental changes in the feeding-induced stimulation of translation initiation in muscle of neonatal pigs. Am J Physiol Endocrinol Metab 2000;279:E1226-E1234. [PubMed: 11093908]

10. Dufner A, Thomas G. Ribosomal S6 kinase signaling and the control of translation. Exp Cell Res 1999;253:100-109. [PubMed: 10579915]

11. Edelmann HM, Kuhne C, Petritsch C, Ballou LM. Cell cycle regulation of p70 S6 kinase and p42/ p44 mitogen-activated protein kinases in Swiss mouse 3T3 fibroblasts. J Biol Chem 1996;271:963971. [PubMed: 8557712]

12. Goke M, Kanai M, Podolsky DK. Intestinal fibroblasts regulate intestinal epithelial cell proliferation via hepatocyte growth factor. Am J Physiol Gastrointest Liver Physiol 1998;274:G809-G818.

13. Gookin JL, Rhoads JM, Argenzio RA. Inducible nitric oxide synthase mediates early epithelial repair of porcine ileum. Am J Physiol Gastrointest Liver Physiol 2002;283:G157-G168. [PubMed: 12065303]

14. Graves LM, He Y, Lambert J, Hunter D, Li X, Earp HS. An intracellular calcium signal activates p70 but not p90 ribosomal S6 kinase in liver epithelial cells. J Biol Chem 1997;272:1920-1928. [PubMed: 8999881]

15. Hara KK, Yonezawa K, Weng QP, Kozlowski MT, Belham C, Avruch J. Amino acid sufficiency and mTOR regulate p70 S6 kinase and eIF-4E BP1 through a common effector mechanism. J Biol Chem 1998;273:14484-14494. [PubMed: 9603962]

16. Iiboshi Y, Papst PJ, Kawasome H, Hosoi H, Abraham RT, Houghton PJ, Terada N. Amino aciddependent control of p70(s6k). Involvement of tRNA aminoacylation in the regulation. J Biol Chem 1999;274:1092-1099. [PubMed: 9873056]

17. Kim JE, Chen J. Cytoplasmic-nuclear shuttling of FKBP12-rapamycin-associated protein is involved in rapamycin-sensitive signaling and translation initiation. Proc Natl Acad Sci USA 2000;97:1434014345. [PubMed: 11114166]

18. Kim SJ, Kahn CR. Insulin stimulates p70 S6 kinase in the nucleus of cells. Biochem Biophys Res Commun 1997;234:681-685. [PubMed: 9175775] 
19. Kim SW, McPherson RL, Wu G. Dietary arginine supplementation enhances the growth of milk-fed young pigs. J Nutr 2004;134:625-630. [PubMed: 14988458]

20. Kimball SR, Jefferson LS. Molecular mechanisms through which amino acids mediate signaling through the mammalian target of rapamycin. Curr Opin Clin Nutr Metab Care 2004;7:39-44. [PubMed: 15090902]

21. Kimball SR, Orellana RA, O'Connor PM, Suryawan A, Bush JA, Nguyen HV, Thivierge MC, Jefferson LS, Davis TA. Endotoxin induces differential regulation of mTOR-dependent signaling in skeletal muscle and liver of neonatal pigs. Am J Physiol Endocrinol Metab 2003;285:E637-E644. [PubMed: 12773308]

22. Li Y, Corradetti MN, Inoki K, Guan KL. TSC2: filling the GAP in the mTOR signaling pathway. Trends Biochem Sci 2004;29:32-38. [PubMed: 14729330]

23. McCormack SA, Viar MJ, Johnson LR. Migration of IEC-6 cells: a model for mucosal healing. Am J Physiol Gastrointest Liver Physiol 1992;263:G426-G435.

24. Pan M, Souba WW, Karinch AM, Lin CM, Stevens BR. Epidermal growth factor regulation of system $\mathrm{L}$ alanine transport in undifferentiated and differentiated intestinal Caco- 2 cells. J Gastrointest Surg 2002;6:410-417. [PubMed: 12022994]

25. Peterson RT, Desai BN, Hardwick JS, Schreiber SL. Protein phosphatase 2A interacts with the 70kDa S6 kinase and is activated by inhibition of FKBP12-rapamycin associated protein. Proc Natl Acad Sci USA 1999;96:4438-4442. [PubMed: 10200280]

26. Pires AL, da Silveira TR, Scholl JG. Relationship between nutritional status and histologic findings in small bowel mucosa of children presenting with diarrhoea of more than 14 days' duration. J Trop Pediatr 1999;45:302-304. [PubMed: 10584475]

27. Polk DB, Tong W. Epidermal and hepatocyte growth factors stimulate chemotaxis in an intestinal epithelial cell line. Am J Physiol Cell Physiol 1999;277:C1149-C1159.

28. Rhoads JM, Argenzio RA, Chen W, Rippe RA, Westwick JK, Cox AD, Berschneider HM, Brenner DA. 1-glutamine stimulates intestinal cell proliferation and activates mitogen-activated protein kinases. Am J Physiol Gastrointest Liver Physiol 1997;272:G943-G1053.

29. Rhoads JM, Chen W, Gookin J, Wu GY, Fu Q, Blikslager AT, Rippe RA, Argenzio RA, Cance WG, Weaver EM, Romer LH. Arginine stimulates intestinal cell migration through a focal adhesion kinase dependent mechanism. Gut 2004;53:514-522. [PubMed: 15016745]

30. Shah OJ, Kimball SR, Jefferson LS. Among translational effectors, p70S6k is uniquely sensitive to inhibition by glucocorticoids. Biochem J 2000;347:389-397. [PubMed: 10749668]

31. Zamora SA, Amin HJ, McMillan DD, Kubes P, Fick GH, Butzner JD, Parsons HG, Scott RB. Plasma 1-arginine concentrations in premature infants with necrotizing enterocolitis. J Pediatr 1997;131:226232. [PubMed: 9290608]

32. Ziegler TR. Glutamine is essential for epidermal growth factor-stimulated intestinal cell proliferation. JPEN J Parenter Enteral Nutr 1994;18:84-86. [PubMed: 8164313]

33. Zijlstra RT, Donovan SM, Odle J, Gelberg HB, Petschow BW, Gaskins HR. Protein-energy malnutrition delays small-intestinal recovery in neonatal pigs infected with rotavirus. J Nutr 1997;127:1118-1127. [PubMed: 9187626] 
A

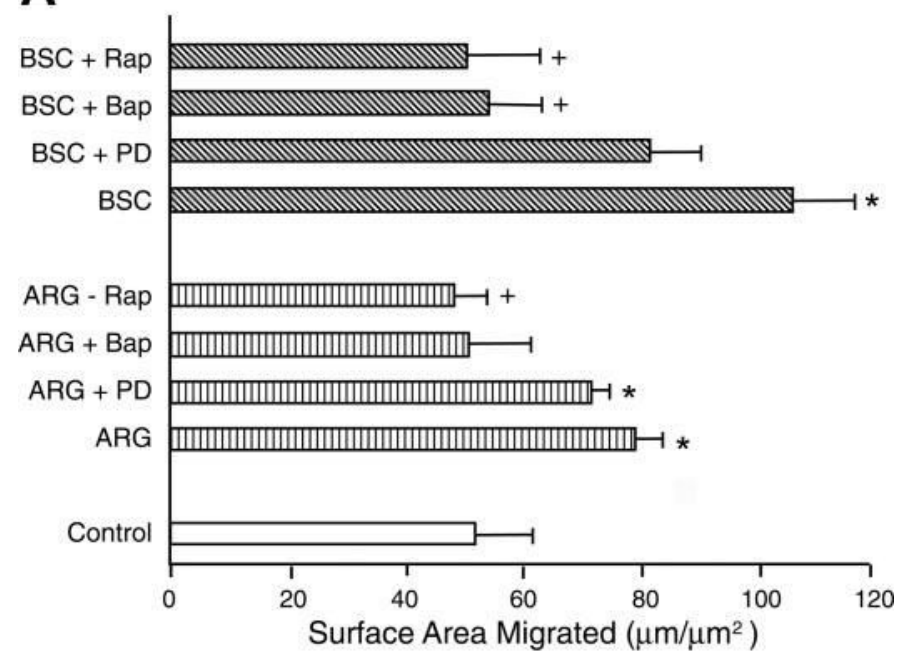

B

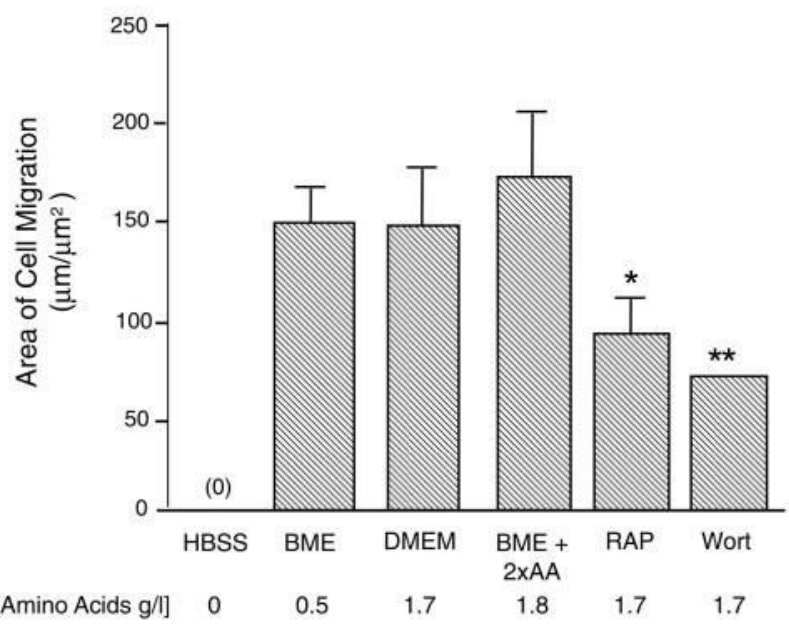

Fig. 1.

A: 24-h cell migration rate of intestinal epithelial cells (IEC) expressed in surface area covered per micrometer of razor wound length. Cells in 6-well plastic plates were starved of serum overnight in DMEM and were subsequently razor-wounded. They were treated with rapamycin (Rap; $50 \mathrm{nM} 30$ min before wounding), BAPTA-AM $(50 \mu \mathrm{M})$, or PD98059 $(50 \mu \mathrm{M})$ alone or with arginine (ARG; $4 \mathrm{mM}$ ) or bovine serum concentrate (BSC; 0.4\%) 30 min before wounding. Migration surface area was then measured $18 \mathrm{~h}$ after wounding. *Indicates migration rate was enhanced, $P \leq 0.05$, compared with control cells. ${ }^{+}$Indicates migration rate was reduced $(P \leq 0.05)$ compared with agonist (ARG or BSC) without inhibitor $(n=3)$. $B$ : Cdx2-tranformed IEC- 6 cells were starved of serum overnight (in BME) and were then placed in HBSS, BME (0.5 g/l amino acids), DMEM with glutamine (1.7 g/l amino acids), BME + $2 \times$ amino acid ( $2 \times \mathrm{AA} ; 1.8 \mathrm{~g} / \mathrm{l}$ amino acids), or DMEM + inhibitor; subsequently, they were razor-wounded. Migration area was measured $24 \mathrm{~h}$ after wounding using computer-assisted morphometry. $* * P \leq 0.01$ compared with cells in DMEM. Wort, wortmannin. 
A

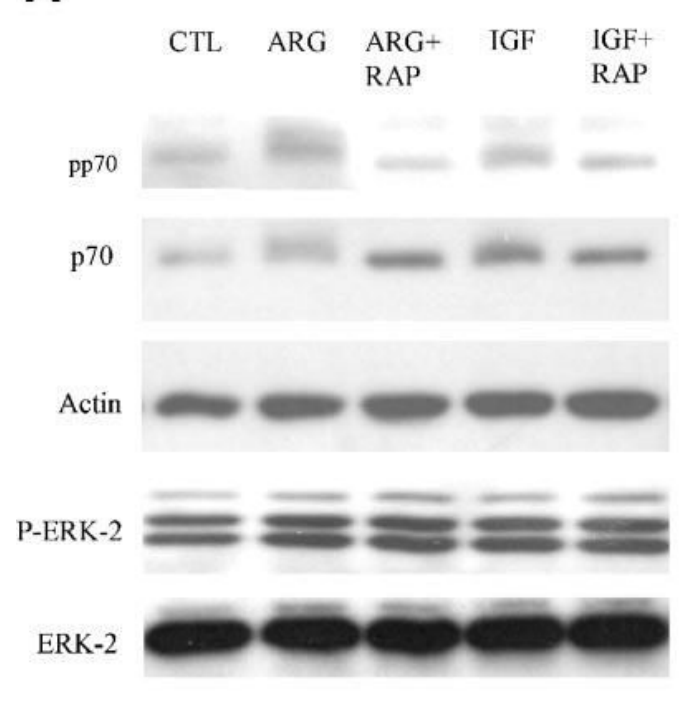

$\mathrm{BME} \longrightarrow$

CTL ARG ARG + IGF IGF+ RAP RAP
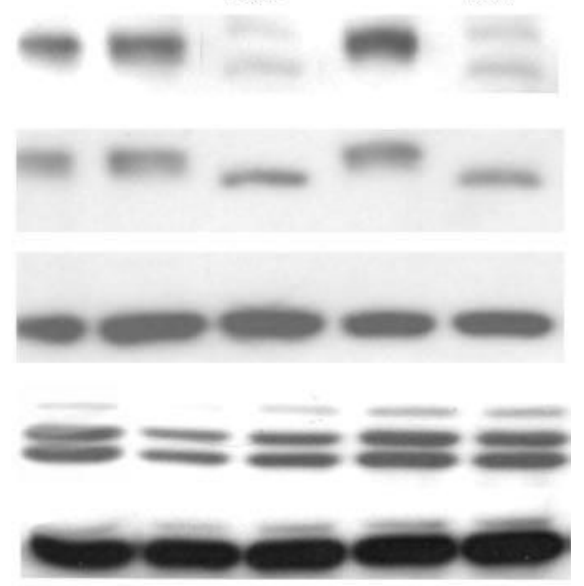

$\mathrm{AA}+\mathrm{Rap}$

$A A+W$

B
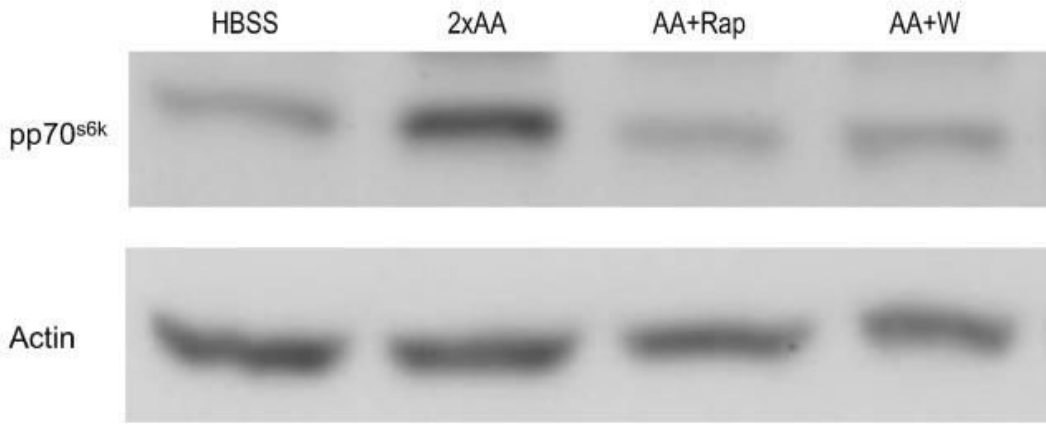

C

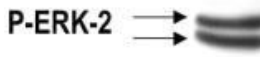

$=$

$\underline{-2}$

$=$

$=$

2

20

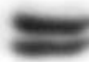

ERK-2

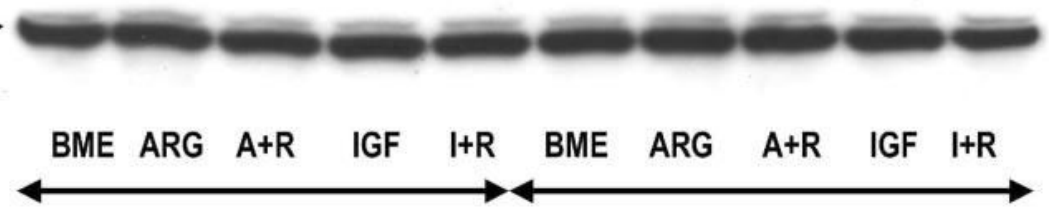

Unwounded

\section{Wounded}

Fig. 2.

A: Western blot showing relative levels of phosphorylated and total $\mathrm{p} 70^{\mathrm{s} 6 \mathrm{k}}$ and ERK-2 in cells treated for $10 \mathrm{~min}$ with ARG or IGF-1 with or without rapamycin. Note that the electrophoretic mobility of $\mathrm{p} 70^{\mathrm{s} 6 \mathrm{k}}$ as well as phosphorylated $\mathrm{p} 70^{\mathrm{s} 6 \mathrm{k}}$ is retarded after treatment with ARG or IGF-1, resulting in an apparently higher molecular weight. Note also that the ARG and IGF-1 activation of $\mathrm{p} 70^{\mathrm{s} 6 \mathrm{k}}$ phosphorylation and mobility shift is abolished by rapamycin. In these studies, parallel groups of cells were bathed in HBSS (left, $0 \mathrm{~g} / \mathrm{l}$ amino acids) or BME (right, $0.5 \mathrm{~g} / \mathrm{l}$ amino acids) and treated with ARG or IGF-1, with or without rapamycin. Note also that control (CTL) cells in HBSS had less pp70 $6{ }^{\mathrm{s}} \mathrm{k}$ than CTL cells in BME. IGF-1- and ARG-treated cells had increased phosphorylation when they were incubed in BME compared with when 
they were incubated in HBSS. Conversely, phosph-ERK-2 levels were not altered by any of the above treatments (bottom 2 panels). $B$ : immunoblot of Cdx2-tranformed IEC-6 cells following treatment with HBSS, $2 x A A, 2 x A A+R A P(50 \mathrm{nM}), 2 x A A+$ Wort $(500 \mathrm{nM})$. Shown is representative of 3 blots probed with anti-phospho-p70 $36 \mathrm{k}\left(\mathrm{pp} 70^{\mathrm{s} 6 \mathrm{k}}\right)$ or anti-actin. $C$ :

immunoblot depicting phospho-ERK-2 level of intestinal cell monolayers either unwounded or wounded for 30 min. Cells in 6-well plates were treated with BME, 4 mM ARG, ARG + rapamycin (R), IGF-1 (I), and I+R. Results from wounded monolayers are shown in lanes 610. 

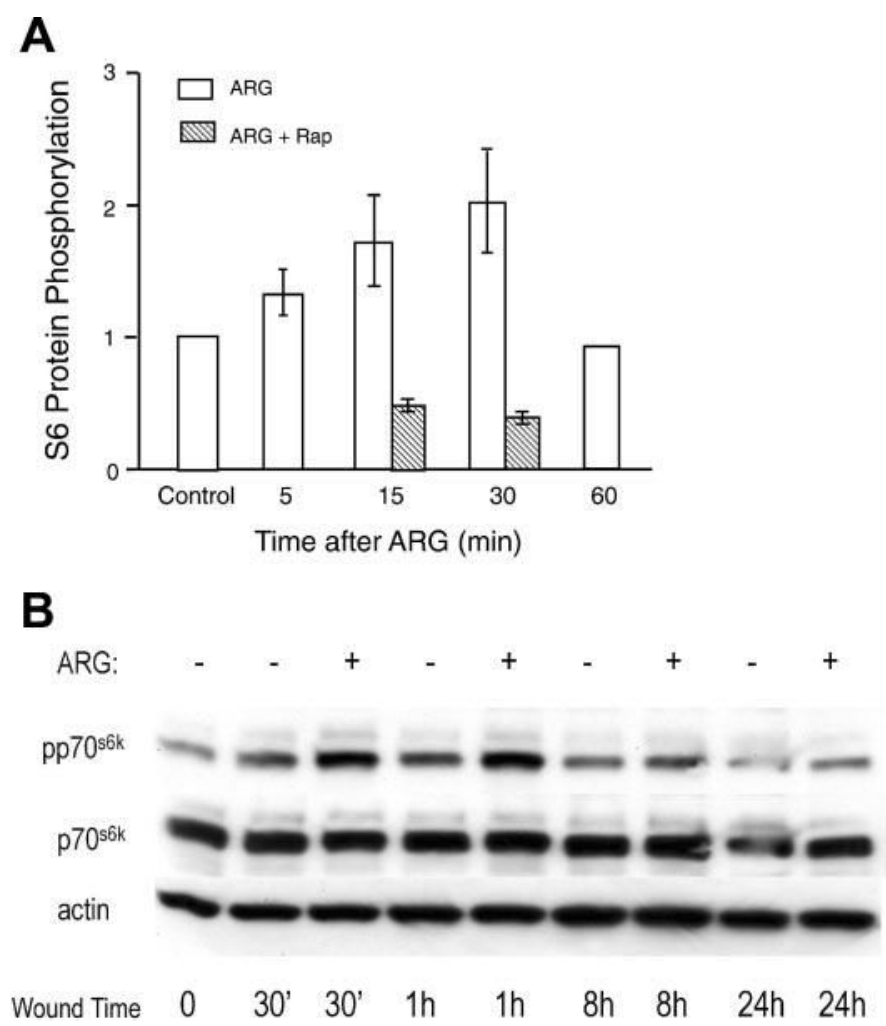

Fig. 3.

$A$ : in vitro kinase activity of $\mathrm{p} 70^{\mathrm{s} 6 \mathrm{k}}$ in unwounded cells treated with $4 \mathrm{mM}$ ARG for varying lengths of time with or without Rap. Where SE bars are indicated, $n=3$ observations. Control phosphorylation level was defined as 1.0. B: effect of $4 \mathrm{mM} \mathrm{ARG}$ supplementation of BME on $\mathrm{p} 70^{\mathrm{s} 6 \mathrm{k}}$ activation after multiple wounding with a pipette tip. Cells were serum-starved overnight and were then placed either in BME with no supplemental ARG $(-; 0.12 \mathrm{mM})$ or BME + supplemental ARG (+; $4 \mathrm{mM})$. Wounding was performed, and cells were harvested $30 \mathrm{~min}$ to $8 \mathrm{~h}$ after wounding and assayed for immuno-reactivity to $\mathrm{p} 70^{\mathrm{s} 6 \mathrm{k}}, \mathrm{pp} 70^{\mathrm{s} 6 \mathrm{k}}$, or actin (as a loading control). 


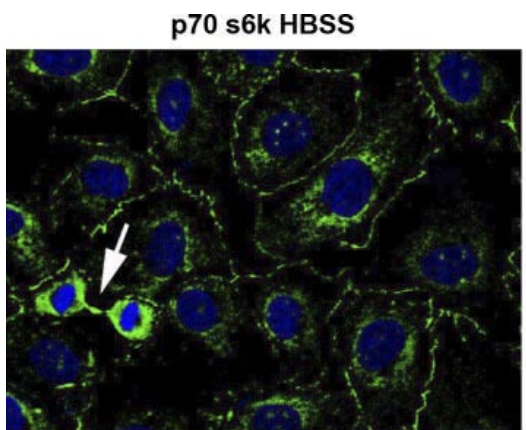

p70 s6k BME

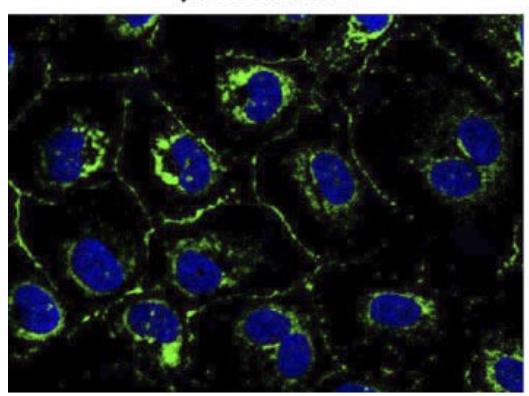

p70 s6k ARG 30min

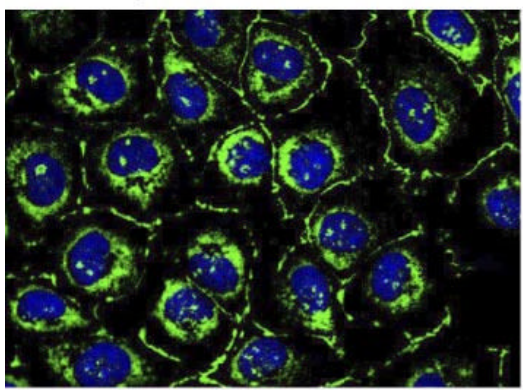

p70 s6k ARG 30min + RAP

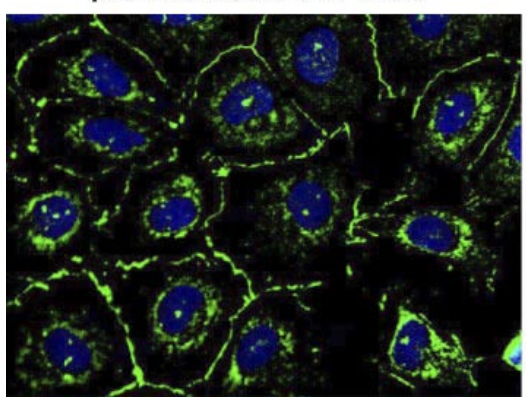

pp70 s6k HBSS

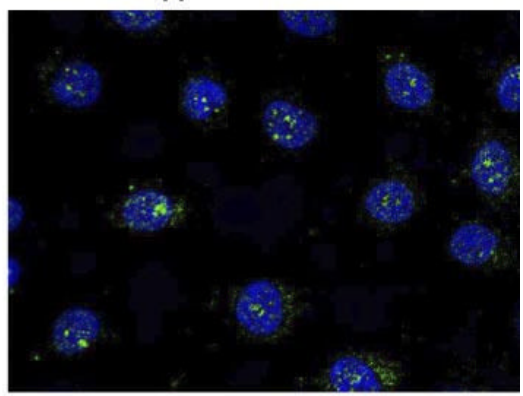

pp70 s6k BME

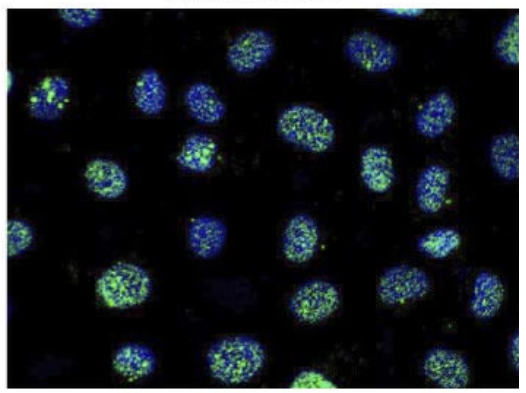

pp70 s6k ARG 30min

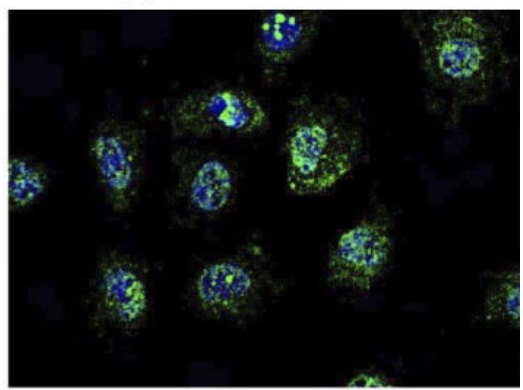

pp70 s6k ARG 30min + RAP

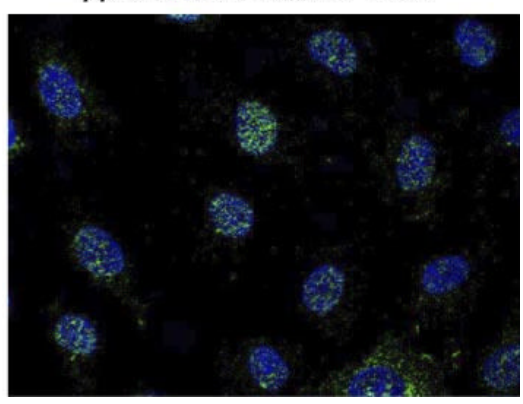

Fig. 4.

Photomicrograph of Cdx2-tranformed IEC- 6 cells, viewed at $\times 63$. Primary antibodies are directed to either $\mathrm{p} 70^{\mathrm{s} 6 \mathrm{k}}$ or $\mathrm{pp} 70^{\mathrm{s} 6 \mathrm{k}}$ shown in green. Nuclear DNA is seen as blue after staining with 4'-6-diamidino-2-phenylin-dole (DAPI). Microscope fluorescence detection parameters were set at identical values for each of the panels shown. Note in left, toppanel that a mitotic figure has markedly increased $\mathrm{p} 70^{\mathrm{s} 6 \mathrm{k}}$ level. Note also that total $\mathrm{p} 70^{\mathrm{s} 6 \mathrm{k}}$ level was higher in ARG (30 min)-treated cells, with strong perinuclear staining and immunoreactivity at cell-cell contact sites. Rapamycin abolished the ARG stimulation. In the right hand panels, one notes that $\mathrm{pp} 70^{\mathrm{s} 6 \mathrm{k}}$ localization is nuclear and higher in the presence of amino acids (BME) than in 
their absence (HBSS). ARG treatment for 30 min increases cytoplasmic localization of $\mathrm{pp} 70^{\mathrm{s} 6 \mathrm{k}}$. The enhancement by ARG of cytoplasmic $\mathrm{pp} 70^{\mathrm{s} 6 \mathrm{k}}$ was abolished by rapamycin. 